\title{
Retinol-binding protein (RBP) and pigmentary dystrophy of the retina
}

\author{
A. H. S. RAHI \\ Department of Pathology, Institute of Ophthalmology, University of London
}

Vitamin A (retinol) is a fat-soluble alcohol and is derived in the upper part of the small intestine from carotenoid plant pigments and Vitamin A esters present in food (Olson, I964). The free retinol then penetrates through the mucosal cells, perhaps aided by its polar or hydrophilic hydroxy group, and is re-esterified during transit (Glover and Walker, 1964). After absorption it reaches the liver, where it is stored chiefly as palmitate (Moore, I 964), and whence it is slowly released into the circulation as free retinol (McLaren, 1970) and combines immediately with a specific transport protein, called retinol-binding protein (Kanai, Raz, and Goodman, I968), to form a protein-retinol complex (i.e. RBPretinol).

One molecule of retinol binds to one molecule of RBP. The molecular complex makes the water-insoluble retinol become soluble and also protects the vitamin against degradation. Retinol-binding protein is a low molecular weight protein (mol. wt. 2 I,0oo) and escapes from the general circulation into the cerebrospinal fluid, the urine, and other tissue fluids (Peterson and Berggard, I97 I). It therefore seems imperative that, in order to prevent an excessive loss of Vitamin A, the RBP-retinol complex should be further attached to a high molecular weight protein.

It has recently been reported that the RBP-retinol complex is further attached to serum pre-albumin (PA) of mol. wt. 64,00o. The complex thus formed is a protein-proteinretinol complex (i.e. PA-RBP-retinol) and has a mol. wt. of 85,00o. Pre-albumin stabilizes the RBP-retinol complex and also serves an important physiological function by preventing glomerular filtration of the relatively small RBP molecule and hence loss of Vitamin A in the urine (Raz and Goodman, 1969).

After reaching the target organ, RBP dissociates from pre-albumin; Vitamin $\mathrm{A}$ is then released and the retinol-binding protein escapes into the urine (Peterson, I97I).

The ocular effects of (Vitamin A-deficient) purified rations were first noted by Osborne and Mendel (I9 I 4), but it was McCollum and Simmonds ( I 9 I 7) who recognized the missing factor and called it "Fat-Soluble A", which was later renamed Vitamin A. It is now known that Vitamin $\mathrm{A}$ is concerned in various metabolic and physiological functions; for example scotopic vision, sulphur metabolism (i.e. activation of sulphate for mucopolysaccharide production), steroid hormone production, and membrane stability (McLaren, 1970). It has been suggested that protein deficiency impairs transport of Vitamin A to the tissue (Arroyave, Wilson, Méndez, Béhar, and Scrimshaw, I96I). It is possible that this impairment is due to a deficiency in the transport protein. 
Estimation of RBP in certain ocular conditions, therefore, should make an interesting and valuable study, especially when it is said that serum levels of Vitamin A cannot always be taken as an index of Vitamin A state in general (McLaren, 1970).

Rats on Vitamin A-deficient diet can be kept alive on synthetic retinoic acid, but the animals lose scotopic vision, suggesting that Vitamin A is essential for retinal metabolism and cannot be substituted by any other metabolite (Dowling and Wald, i 958). Electronmicroscopic studies (Amemiya, I97I) suggest that in Vitamin A deficiency the degeneration begins in the pigment epithelium and then extends to the outer segments of the photoreceptor cells. The collagen fibres of Bruch's membrane lose their periodicity and become hollow like a tube (Amemiya, i 969). Since the outer retina is nourished by the choriocapillaris for a distance of between $\mathrm{I} 20$ and $\mathrm{I} 4 \mathrm{O} \mu$, the changes in pigment epithelium and Bruch's membrane may very well interfere with the transport of metabolites to and from the retina and so lead to retinal degeneration.

Pigmentary dystrophy of the retina in man (and animals) is characterized by progressive degeneration of the neuroepithelium. So far we are ignorant of the aetiology of this condition (Duke-Elder and Dobree, I 967 ), but it is possible that some cases are due to a deficiency of Vitamin A (Campbell, Harrison, and Tonks, 1964). This deficiency could be related to a low level of retinol-binding protein. Since a low serum value for Vitamin A is not a constant feature of retinitis pigmentosa (Krachmer, Smith, and Tocci, I966), Cogan (I950) believed that patients with retinal dystrophy might be unable to utilize Vitamin A. A quantitative or qualitative deficiency of RBP could lead to Vitamin A deficiency, at least at the retinal level, and an estimation of this protein in the serum of patients with retinal degeneration may therefore afford some insight into this bafflingo human malady.

So far, retinol-binding protein has been ioslated from human serum by chromatograph on DEAE-sephadex (Kanai and others, I 968) or on arginine-sephrose (Kirby, White; and Glover, I 97 I), but a recent study (Peterson and Berggård, I 97 I) suggests that immunochemical methods could be used to estimate this biologically active and important protein. Antisera against human RBP are now commercially available (from Hoechst Pharmaceuticals) and it should therefore be possible for routine immunological laboratories to estimate the level of this protein in various ocular conditions.

\section{Patients and experimental methods}

Blood was collected from $5 \mathrm{I}$ patients ( 28 males and 23 females), with retinitis pigmentosa and from nine carriers (all females) of the disease. The serum was stored at $-30^{\circ} \mathrm{C}$. until use. Reference serum was prepared after the method of Hobbs (1970), by mixing sera from ten healthy adult males and ten healthy adult females, and treated as roo per cent. mean normal adult (MNA).

The retinol-binding protein was estimated by the single radial immunodiffusion method of Mancini, Carbonara, and Heremans (1965). Antiserum agar plates were prepared by mixing $6 \mathrm{ml}$. of 2 per cent. Noble agar in ordinary electrophoresis barbitone buffer with $0.2 \mathrm{ml}$. of anti-RBP serum and $\mathrm{r} \cdot 8 \mathrm{ml}$. of one per cent. sodium azide, and then pouring it into a $9-\mathrm{cm}$. Petri dish. After the agar was set the plates were kept at $4^{\circ} \mathrm{C}$. overnight. Wells of $2 \mathrm{~mm}$. diameter were cut $\mathrm{I} \mathrm{cm}$. apart and filled to the level with microtip pasteur pipettes attached to mouth pieces.

Different dilutions of reference serum were used to obtain a standard curve. The plates were left at room temperature for 2 days for the rings to develop and then washed with saline and stained with nigrosine. The RBP concentration of the reference serum was plotted vertically on a log. scale against the precipitin ring diameter on the linear scale. The RBP values of the test sera were then read off as percentages of the mean normal adult (MNA). This is an accepted mode of expressing serum values of protein like immunoglobulins, transferrin, etc. (Hobbs, I970). 


\section{Results}

As shown in Table I, the patients could be grouped into a major group $I$ and a minor group II. Group I consisted of 82 per cent. of the patients and showed a mean RBP value of 76 per cent. of MNA ( $\left.P<0^{\cdot 00 I}\right)$. Only 18 per cent. (Group II) patients had normal or above normal RBP values.

Table I Values for retinol-binding protein in retinitis pigmentosa (5 $\mathrm{I}$ patients and 8 carriers)

\begin{tabular}{|c|c|c|c|c|c|c|c|c|}
\hline \multirow[t]{2}{*}{ Group } & \multirow{2}{*}{\multicolumn{2}{|c|}{ Total no. of patients }} & \multicolumn{2}{|c|}{ Mean as percentage of $M \mathcal{N} A$} & \multicolumn{2}{|c|}{$\begin{array}{l}\text { Range as percentage } \\
\text { of } M \mathcal{N} A\end{array}$} & \multicolumn{2}{|c|}{$\begin{array}{l}\text { Percentage of total } \\
\text { patients }\end{array}$} \\
\hline & & & Sexwise & Overall & Sexwise & Overall & Sexwise & Overall \\
\hline \multirow{2}{*}{ I } & \multirow{2}{*}{42} & MALES (25) & $(\mathrm{S} . \mathrm{D}=13 \cdot \mathrm{I})$ & \multirow{2}{*}{76} & $50-102$ & & 89 & \multirow{2}{*}{82} \\
\hline & & $\overline{\text { FEMALES (1 7) }}$ & $\begin{array}{l}8 \mathrm{r} \\
(\mathrm{S} . \mathrm{D}=16 \cdot 3)\end{array}$ & & 48-102 & & 75 & \\
\hline \multirow{2}{*}{ II } & \multirow{2}{*}{9} & MALES (3) & $\begin{array}{l}\text { II } 8 \\
(S . D=8 \cdot 0)\end{array}$ & \multirow{2}{*}{$120 \cdot 5$} & $110-126$ & & II & \multirow{2}{*}{18} \\
\hline & & FEMALES (6) & $(S . D=12 \cdot 1)$ & & $110-132$ & $110-132$ & 25 & \\
\hline$\underset{\text { (carriers) }}{\text { III }}$ & 8 & (all females) & \multicolumn{2}{|c|}{69} & \multicolumn{2}{|c|}{$52-86$} & \multicolumn{2}{|c|}{100} \\
\hline
\end{tabular}

All the nine sera (Group III) from the carriers showed a low value of RBP, the mean being 69 per cent. of MNA. The RBP values in the patients show a clear tendency for a shift to the left of the mean normal adult values (Figure).

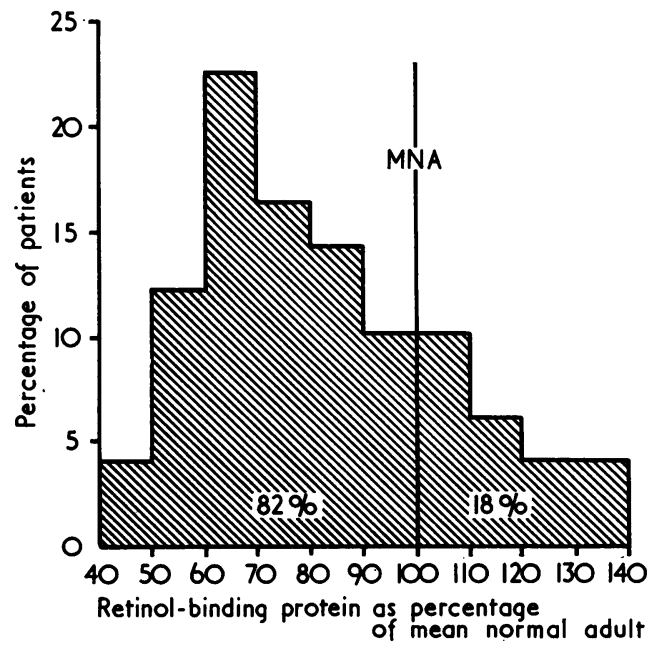

FIGURE Frequency distribution of plasma RBP in retinitis pigmentosa

Two-way analysis of variance was performed by the computer department of this Institute and the results obtained are shown in Table II (overleaf).

\section{Comment}

It has been claimed that the most significant biochemical finding in pigmentary retinal dystrophy is that of the persistently low level of Vitamin A in 9I per cent. of the adult patients (Campbell and Tonks, 1962). 
Table II Analysis of Variance

A-Sex (Male; Female) B-Type (Group I; Group II)

\begin{tabular}{|c|c|c|c|c|c|}
\hline Source & SS & $D F$ & $M S$ & $F$ & $P$ less than \\
\hline A-Sex & 3519.211 & I & $35^{19 \cdot 211}$ & $17 \cdot 871$ & o.oor highly significant \\
\hline B-Type & 14153.559 & $\mathbf{I}$ & 14153.559 & $71 \cdot 837$ & $0 \cdot 00$ I highly significant \\
\hline A-B interaction & $4^{1} \cdot 685$ & I & $4^{1} \cdot 658$ & 0.212 & $0 \cdot 648$ not significant \\
\hline Residual & $9255 \cdot 43^{8}$ & 47 & $196 \cdot 924$ & & \\
\hline
\end{tabular}

The low level of retinol may lead to chronic starvation of the retina and subsequent progressive degeneration. A low serum value of RBP as estimated in the present study could account for the low values of Vitamin A. Since retinal metabolism is dependent upon Vitamin A (retinol) and cannot be substituted by Vitamin A acid, a mild deficiency in the transport protein is likely to affect the retina most commonly. Reports that Vitamin A levels may not be low in every case of retinitis pigmentosa (Krachmer and others, I966) do not invalidate the implications of a low level of retinol-binding protein. Deficiency of RBP could lead to an accumulation in the plasma of unbound retinol so that, although the total amount of Vitamin A may not be low at a given time, the fact that it is unbound to its carrier protein may lead to its early and excessive degradation and loss of effectivity. If this is true, then perhaps we are dealing with a situation quite analogous to Wilson's disease, in which low levels of ceruloplasmin lead to the accumulation of free copper. Furthermore, very little is known of the mechanisms involved in the dissociation of RBP from retinol, and it is possible that free Vitamin A may act upon this mechanism adversely, thus affecting the transport of the protein-retinol complex to the target organs. Serum levels of RBP could also influence the release of free retinol from its depot forms in the liver.

Since 75 to 80 per cent. of the total ocular Vitamin A is found in the pigment epithelium of the retina, it is possible that with a deficiency of RBP sufficient amounts of free retinol collect in the plasma and then pass out into the pigment epithelium of the retina (its natural depot) and so damage the lysosomal membranes to release hydrolytic enzymes and cause autodestruction.

Indeed, it is known that Vitamin A causes release of lytic enzymes from lysosomes (Dingle, I96I) and that the lysosomes of the pigment epithelium of dystrophic animals are relatively unstable (Burden, Yates, Reading, Bitensky, and Chayen, 1971). Since only 0.005 per cent. of the total Vitamin $A$ is found in the eye (Moore, 1964), it is not difficult to imagine that even a slight rise in free retinol in the plasma could lead to its abnormal accumulation in the pigment epithelium with subsequent damage to the already unstable lysosomes.

\section{Summary}

Retinol-binding protein has been estimated for the first time in the serum of patients with retinal dystrophy. Of the $5 \mathrm{I}$ patients examined, 82 per cent. showed a low level of RBP, the average being 76 per cent. of the mean normal adult value. It is possible that low levels of RBP could lead to low plasma values for retinol and a consequent poor supply to the retina, leading to chronic tissue starvation and degeneration. A low RBP value could also lead to an accumulation of free retinol in the circulation with an eventual 
higher concentration in the pigment epithelium of the retina; this could damage the labile lysosomes, leading to tissue destruction. How the low levels of RBP could be aetiologically related to retinal degeneration is purely conjectural and further work is required before any definite explanation can be offered.

I thank Prof. Norman Ashton, F.R.S., for his valuable advice and helpful criticism, Miss G. G. Munn for technical assistance, and Miss B. A. Streek for preparation of manuscript. This study was supported by a grant from the Leverhulme Trust.

\section{References}

AмEмrya, т. (1969) Acta Soc. ophthal. 7ap., 73, 751 (197 I) Eye, Ear, Nose Thr. Mthly, 50, 34I

ARroyave, G., Wilson, D., méndez, J., BÉhar, M., and scrimshaw, N. s. (I96i) Amer. J. clin. Nutr., 9, 180

Burden, E. M., yAtes, c. M., ReAding, H. w., Bitensky, L., and chayen, J. (197 I) Exp. Eye Res., 12, I 59

CAMPBEll, D. A., hARRISON, R., and TONKS, E. L. (1964) Ibid., 3, 41 2

- and TONKs, E. L. (I962) Brit. 7. Ophthal., 46, I5I

Cogan, D. G. (1950) Trans. Amer. Acad. Ophthal. Otolaryng., 54, 629, $63^{8}$

DINGLE, J. T. (I96I) Biochem. 7., 79, 509

Dowling, J. E., and WAld, G. (1958) Proc. nat. Acad. Sci., 44, 648

DUKE-ELDER, S., and DOBREE, J. H. (1967) "System of Ophthalmology", vol. 10, p. 6o2. Kimpton,

London

GLOVER, J., and WALKer, R. J. (I964) Exp. Eye Res., 3, 374

hobBs, J. R. (1970) ACP Broadsheet No. 68. B.M.A., London

kANAI, M., RAz, A., and goodman, DeW.s. (I968) 7. clin. Invest., 47, 2025

KIRBY, W., WHITE, G., and Glover, J. (I97I) Biochem. F., 123, 3 IP

Krachmer, J. H., SMith, J. L., and tocai, P. м. (I966) Arch. Ophthal. (Chicago), 75, 66 I

McCollum, E. v., and simmonds, N. (1917) J. biol. Chem., 32, 181

McLAREN, D. S. (1970) In "Biochemistry of the Eye", ed. C. N. Graymore, p. 519. Academic Press,

London

MANGINI, G., CARBonaRA, A. O., and heremans, J. F. (I965) Immunochemistry, 2, 335

MOORE, T. (1964) Exp. Eye Res., 3, 305

olson, J. A. (1964) J. lipid Res., 5, 402

OSBORNE, T. B., and MENDEL, L. B. (1914) 7. biol. Chem., 17, $40 \mathrm{O}$

PETERSON, P. A. (I97 I) Ibid., 246, 34

—— and BERGGÅRD, I. (I97I) Ibid., 246, 25

RAZ, A., and GOODMAN, DeW.s. (1969) Ibid., 244, 3230 